IZA DP No. 6581

The Quest for More and More Education: Implications for Social Mobility

Joanne Lindley

Stephen Machin

May 2012 


\title{
The Quest for More and More Education: Implications for Social Mobility
}

\author{
Joanne Lindley \\ University of Surrey \\ Stephen Machin \\ University College London, \\ CEP, London School of Economics and IZA
}

\author{
Discussion Paper No. 6581 \\ May 2012
}

IZA

P.O. Box 7240

53072 Bonn

Germany

Phone: +49-228-3894-0

Fax: +49-228-3894-180

E-mail: iza@iza.org

\begin{abstract}
Any opinions expressed here are those of the author(s) and not those of IZA. Research published in this series may include views on policy, but the institute itself takes no institutional policy positions.

The Institute for the Study of Labor (IZA) in Bonn is a local and virtual international research center and a place of communication between science, politics and business. IZA is an independent nonprofit organization supported by Deutsche Post Foundation. The center is associated with the University of Bonn and offers a stimulating research environment through its international network, workshops and conferences, data service, project support, research visits and doctoral program. IZA engages in (i) original and internationally competitive research in all fields of labor economics, (ii) development of policy concepts, and (iii) dissemination of research results and concepts to the interested public.
\end{abstract}

IZA Discussion Papers often represent preliminary work and are circulated to encourage discussion. Citation of such a paper should account for its provisional character. A revised version may be available directly from the author. 


\section{ABSTRACT \\ The Quest for More and More Education: Implications for Social Mobility*}

In this paper, we discuss the quest for more and more education and its implications for social mobility. We document very rapid educational upgrading in Britain over the last thirty years or so and show that this rise has featured faster increases in education acquisition by people from relatively rich family backgrounds. At the same time, wage differentials for the more educated have risen. Putting these two together (more education for people from richer backgrounds and an increase in the payoff to this education) implies increasing within generation inequality and, by reinforcing already existent inequalities from the previous generation, this has hindered social mobility. We also highlight three important aspects that to date have not been well integrated into the social mobility literature: the acquisition of postgraduate qualifications; gender differences; and the poor education performance of men at the lower end of the education distribution.

JEL Classification: J24, J31

Keywords: education, wages, inequality, social mobility

Corresponding author:

Stephen Machin

Department of Economics

University College London

Gower Street

London, WC1E 6BT

United Kingdom

E-mail: s.machin@ucl.ac.uk

\footnotetext{
* We would like to thank Claire Crawford for a number of helpful comments and suggestions. We are also grateful to the Sutton Trust for partially funding this work.
} 


\section{Introduction}

The British population currently holds more educational qualifications than at any point before. The quest for more and more education has arisen from the view that more education enhances individual productivity and generates a wage payoff. Indeed, evidence shows that this holds in the context of modern labour markets. Despite the supply of more educated workers rising very rapidly in the last three decades, wage differentials between workers with more education and workers with less education have risen over time as employers have increased their demand for high education individuals. ${ }^{1}$

Rising education levels and educational wage differentials not only matter for inequality within generations, but also have potentially important implications for the level of social mobility across generations and for its evolution through time. If individuals from wealthy backgrounds acquire more education and get a wage payoff for this education, already existing inequalities are transmitted more strongly across generations and social mobility falls.

Research shows this to have been a feature of recent experience in Britain. Blanden, Goodman, Gregg and Machin (2005) compare the cross-generation correlation of income for two British birth cohorts (the first born in 1958, the second born in 1970) and show this correlation rose significantly across these birth cohorts. Thus, social mobility fell. A key aspect of this fall was an increased sensitivity of degree acquisition to family income (Blanden and Machin, 2004). Further investigation (by Blanden and Machin, 2008) reveals that there appears to have been a step change down in social mobility levels for these cohorts who respectively were of the age to go to higher education in the late 1970s/early 1980s and late1980s/early 1990s. For cohorts born after

\footnotetext{
${ }^{1}$ See Acemoglu and Autor (2010) for a recent comprehensive review of this work.
} 
this, the level of social mobility probably did not deteriorate further. Neither, though, did it improve.

A great deal of concern has been expressed in many quarters about these trends and they have generated a lot of subsequent research and controversy. ${ }^{2}$ Nevertheless, certain aspects of rising inequality and falling social mobility remain not well understood. There is still a need to generate a better understanding of the ways in which higher educational levels have produced economic benefits for some individuals and how these have translated into changing levels of social mobility. This forms the focus of this paper, where we examine in some detail how the quest for more and more education has affected inequality within generations and mobility across generations.

The rest of the paper is structured as follows. Section 2 describes trends in education acquisition and in educational inequalities. Section 3 considers how these changing patterns have mapped into wage inequality trends through changes in educationrelated wage differentials. Section 4 discusses the implications for social mobility, whilst Section 5 offers some concluding remarks.

\section{Trends in Education Acquisition and Educational Inequality}

\section{Education Acquisition Over Time}

Increased time spent in education and acquisition of more educational qualifications have occurred over time in many countries. In Britain, the post Second World War period saw successive cohorts of individuals spend more time in education, with more people staying on after the compulsory school leaving age (now 16, following an increase from 15 to 16

\footnotetext{
${ }^{2}$ See the debate about whether mobility really fell across the 1958 and 1970 cohorts between Blanden, Gregg and Macmillan (2011) and Erikson and Goldthorpe (2010). These sets of authors agree that income mobility fell across the 1958 and 1970 cohorts, whilst social class mobility did not. Blanden, Gregg and Macmillan (2011) reconcile the differences by noting that income inequality rose within social class groups over time so that one sees no between-group change in social class mobility, but that the fall in income mobility occurs within social class groupings. See also Ermisch and Nicoletti (2007) who report falling mobility from British Household Panel Survey data for the same birth cohorts.
} 
in 1973, and from 14 to 15 in 1947) and more people continuing on to higher education after that. At the same time, qualification attainment has risen. There is, of course, contemporary policy relevance here with the proposed increases in the leaving age (first to 17 , then to 18) that will occur in due course.

The higher education (HE) dimension of increased education is shown in Figure 1. The Figure shows the percentage of the relevant age cohorts entering HE over the last thirty years or so, from 1981 to the most recent year when data is available, 2009. Two series are shown. The first is the Age Participation Index (API), the number of domiciled young people (aged less than 21) who are initial entrants to full time and sandwich undergraduate courses as a percentage of the 18 to 19 year old GB population. The API was discontinued in 2001 and replaced by the Higher Education Initial Participation Rate (HEIPR), which has a different definition as it covers entrants to HE from different age groups (the one in the Figure covers ages 17 to 20).

The Figure shows a very clear upward trend in higher education participation. The API rises from 13 percent in 1981 to 35 percent by its last year, $2001 .^{3}$ The rise was very rapid for cohorts entering HE in the early 1990s (i.e. those born in the early 1970s). Despite plateauing out a little after this, there are still year on year rises that continue to 2009 (and interesting blips in 1998 and 2006 where the HE financing regime was changed). The second series, the HEIPR, rises from 31 percent in 1999 to 37 percent by 2009.

Rising qualification attainment has also occurred over time. This is considered in Table 1. The Table uses Labour Force Survey data for Great Britain to show trends in employment shares between 1981 and 2011 in five education categories. ${ }^{4}$ Four of these

\footnotetext{
${ }^{3}$ Our focus is on the past thirty years, but this upward trend pre-dates the start of the series shown in the Figure. For example, the API was 6 percent in 1961.

${ }^{4}$ We focus on Britain, dropping observations from Northern Ireland from the Labour Force Survey, which is a UK wide survey, to maintain comparability with the British cohort data we also analyse.
} 
are observed for the whole period, whilst the HE category can be further disaggregated in a consistent manner through time from 1996 onwards (see the Data Appendix for more details). Ordered from lowest to highest, the categories are:

i) No qualifications.

ii) Intermediate A - if an individual's highest qualification is a school-level qualification up to and including A levels (or an equivalent level diploma via further education).

iii) Intermediate B - if an individual's highest qualification is a professional qualification, or a teaching and nursing qualification.

iv) Undergraduate degree or higher.

The last group, undergraduate degree or higher, can be further split from 1996 onwards (from when a consistent definition over time exists) into those with an undergraduate degree only and those who continue to get a postgraduate qualification.

The pattern of change shown by the numbers in the Table is striking. Over the last thirty years, a huge educational upgrading has occurred. In 1981, 58 percent of the adult (aged 26-60) workforce had no qualifications. In the same year, 5 percent had a degree. By 2011, the percent without qualifications fell to a mere 5 percent, whilst 31 percent had a degree.

There were also sharp gender inequalities in education in 1981, as described in panels B and C of the Table that show employment shares for men and women separately. In 1981, 62 percent of adult women had no qualifications and only 3 percent had a degree. Comparable percentages for adult men were 55 and 7. By 2011 convergence has occurred, and the proportions in each of the education groups in the Table are almost identical among men and women. This catch-up, or more rapid expansion, for women is an important feature of the educational upgrading that has occurred. We will return to the implications for social mobility later in the paper. 
The expansion of HE has also seen a rise in the number of workers who do not stop their education at the end of their undergraduate studies, but rather go on to get a postgraduate qualification. We can only show number from 1996 onwards (owing to definition changes in the LFS), but the share of the adult workforce with a postgraduate qualification goes from 4 percent in 1996 to 11 percent by 2011. The percentage doubles for men (from 5 to 10 percent), but it triples for women (from 3 to 10 percent). This, too, has potentially important implications for social mobility that we will consider later.

It is also interesting to consider variations by different postgraduate qualification. Table 2 therefore looks at what qualifications postgraduates have been obtaining by looking at employment shares within the postgraduate group between 1996 and 2011. It is evident that the share of Masters degrees has risen, whilst in relative terms the Doctorate share has fallen. This pattern is qualitatively the same for men and women, though somewhat more pronounced for men.

Educational Inequality Over Time

When studying the social mobility implications of this education expansion, one needs to consider from which part of the family income distribution the most rapid upgrading has occurred. Some previous work has considered this question. Blanden and Machin (2004) show that HE expansion (measured by degree acquisition by age 23) was much faster for people from the top 20 percent of the income distribution than for the middle 60 percent, where in turn it was faster for the bottom 20 percent: it more than doubled (from 20 percent to 46 percent between 1981 and 1993) for the top quintile, rose by less (from 8 to 23 percent) for the middle 60 percent, and barely rose at all (going from 6 to 9 percent) for the bottom quintile. Thus educational inequality significantly rose, and in turn led to reduced social mobility. 
We reconsider this question, studying cross-cohort changes in educational inequality more comprehensively. We first consider changes in qualification attainment and its relation to family income across the whole education distribution (not just degree acquisition) and second we break down HE into undergraduate and postgraduate study. ${ }^{5}$ We also consider gender differences in more detail.

We do this using the same British birth cohort datasets, but now measuring educational qualifications at age 33/34 in 1991 and 2004, respectively from the National Child Development Study, the birth cohort of everyone born in Great Britain in a week of March 1958, as well as the British Cohort Study (BCS), the birth cohort of everyone born in a week of April 1970. To study educational inequality, we have calculated the proportion of each education group within family income quintiles (measured when the cohort member was age 16). These are reported for the four main education groups in Table 3, for both cohorts and for the lowest 20 percent of family income, the middle 60 percent and the highest 20 percent.

The top panel of Table 3 shows the education shares by income group for all cohort members. It is evident that, for both cohorts, education levels are lower in the bottom 20 percent of family incomes and highest in the top 20 percent. Moreover, the gaps are large. For example, for the 1958 cohort, degree acquisition in the lowest 20 percent of family incomes is only 9 percent, compared to 28 percent in the top 20 percent of family incomes (and 12 percent in the middle 60 percent). At the bottom of the education spectrum, there is a bigger share with no qualifications (at 14 percent) in the bottom quintile, as compared to 4 percent in the top. This suggests wide educational inequalities in terms of qualification attainment across the family income distribution.

\footnotetext{
${ }^{5}$ See also Gregg and Macmillan (2010) for a consideration of education-family income correlations for different education levels.
} 
Looking at the BCS shares, one identifies the same kind of pattern, but the inequalities are more marked. Take the case of degree acquisition. The share in the bottom quintile barely improves when compared to the NCDS bottom quintile (10 percent versus 9 percent), but the share getting an undergraduate degree or higher in the top quintile increases by a lot (to 37 percent from 28 percent in the NCDS). ${ }^{6}$

Gaps between the top and bottom quintile also widen for the other three education shares, showing an increase in cross-cohort educational inequalities. ${ }^{7}$ Put differently, family income matters more for the BCS cohort's educational attainment than it did for the NCDS cohort. Even though stark educational inequalities were in place for the latter, educational attainment actually became more unequal over time.

The gender dimension is interesting as well. Both men and women see widening out of education gaps by family income quintile across the cohorts. Moreover, the position among graduates looks very similar for men and women. In the rest of the distribution women are doing just as well, if not better than men. For example, in the BCS cohort 15 percent of men from the bottom 20 percent of family incomes have no qualifications as compared to only 9 percent of women.

In Table 4, we probe the graduate differences in more detail. By their early thirties, it is evident that graduates can also have obtained postgraduate qualifications after their first degree. One key feature (as highlighted by Lindley and Machin, 2011) of the increased demand for graduates that has occurred through time has been the fact that many graduates now do not stop at the end of their undergraduate studies, but go on to obtain a postgraduate degree. This aspect of the quest for more and more education has, to date,

\footnotetext{
${ }^{6}$ The use of data at an older age (33 in NCDS, 34 in BCS) provides an interesting contrast with the numbers in Blanden and Machin (2004) who looked at degree acquisition by age 23. Our NCDS age 33 numbers show slightly higher shares further up the education distribution, suggesting people from the NCDS cohort acquired more education after age 23. This 'second chance' aspect is seen much less in the BCS cohort where our age 34 numbers are closer to the Blanden and Machin (2004) age 23 numbers.

${ }^{7}$ See Belley and Lochner (2007) for US evidence (based on a cross-cohort comparison of the 1979 and 1997 National Longitudinal Survey of Youth) that family income has become a more important determinant of college attendance over time.
} 
been a rather understudied aspect of rising wage inequality and, to our knowledge, has not been studied at all in the social mobility literature.

Table 4 therefore shows how HE qualifications vary by family income for those graduates who only have an undergraduate degree and for those who also have a postgraduate qualification. The upper panel of the Table shows results for all cohort members and also considers HE inequality as the gap between the education shares of the top quintile relative to the bottom quintile of the family income distribution. As we have already seen in the discussion around Table 3, HE inequality widened across the cohorts. For all graduates, HE inequality went up from 0.19 for the 1958 cohort to 0.27 for the 1970 cohort, showing a rise of 0.08 . The Table shows that, for all cohort members, this is divided half and half amongst those with only an undergraduate qualification and those with a postgraduate qualification (both rising by 0.04 ).

In terms of gender, considered in panels $\mathrm{B}$ and $\mathrm{C}$ of Table 4, patterns of change are similar, with males seeing postgraduate $\mathrm{HE}$ inequality rise a bit more, and females seeing undergraduate HE inequality go up by marginally more. However, the changes are quite similar, suggesting that the postgraduate dimension of rising educational inequality is an important dimension that research has not studied.

\section{Trends in Educational Wage Differentials}

In terms of education, in order to consider the other side of the social mobility coin, we have to look at the wage payoffs individuals obtain in the labour market. If the groups who have acquired more education (i.e. those from the upper part of the family income distribution) also get a bigger wage payoff, then this exacerbates already existent inequalities and reduces social mobility. 
In this section, we therefore consider what has happened to wage differentials between education groups over time. Since the graduates are those whose education has risen more rapidly, and they are increasingly from wealthy families, it is this group of individuals we choose to focus upon. As in the last section, we first show what has happened for the overall adult workforce using Labour Force Survey data through time, and then focus on the cross-cohort comparisons in more detail.

\section{Changes in LFS Wage Differentials by HE Group}

Table 5 shows LFS wage differentials for the composite graduate education groups between 1996 and 2011. These are estimated firstly on a pooled sample of male and female full time workers and results are presented in panel A, but then also separately by gender where the results are presented in panels B and C. These are conditional log wage differentials with respect to the intermediate A level of highest qualification, where the wage equations also include controls for gender (in Panel A), a quadratic in age, being of white ethnicity, being married/cohabiting, working in a private sector job and for government office region.

The first row of panel A shows that the relative wages of all college graduates as compared to intermediate A workers increased over time by 0.029 log points, rising from 0.428 in 1996 to 0.457 in $2011 .^{8}$ The subsequent rows however, show that there have been important differences in the growth of wages by qualification within this graduate group. The rise in the college graduate wage premium from 1996 to 2011 has only occurred for those who have stayed on after their first degree. Indeed, the postgraduate wage differential increased by $0.075 \log$ points (from 0.470 in 1996 to 0.545 in 2011), whereas the wage premium for undergraduate workers basically stayed flat over this time period

\footnotetext{
${ }^{8}$ As noted in the Data Appendix, intermediate A contains school level qualifications up to and including A levels. We prefer to compare to this broader group of qualifications, in part for reasons of sample size, but restricting to A levels only as the comparison group produced a similar pattern of changing relative wage differentials. For example, the Undergraduate Degree or Higher differential (standard error) rose by 0.041 (0.021) between 1996 and 2011 as compared to the $0.029(0.012)$ in the Table.
} 
(increasing by a statistically insignificant $0.006 \log$ points). ${ }^{9}$ Indeed the strengthening of the relative wage position of postgraduate vis-à-vis undergraduate workers can be clearly seen in the final row of panel A. The postgraduate/undergraduate wage differential increased by $0.068 \mathrm{log}$ points (from $0.060 \mathrm{log}$ points in 1996 to 0.129 in 2011). These patterns are consistent with those found both for Great Britain and the United States in Lindley and Machin (2011) which suggest that faster relative graduate wage growth for postgraduates is not only a British phenomenon.

Figure 2 shows the year on year evolution of the postgraduate/undergraduate wage differential. The overall upward trend between 1996 and 2011 is characterised by a sharp rise up in the late 1990s and early 2000s, followed by relative stability, and then the suggestion of another rise in the most recent years. It does seem that staying on in higher education after acquisition of a first degree and obtaining postgraduate qualifications is increasingly paying off through time.

An important addition to the existing literature is to investigate whether the wage growth of postgraduates relative to undergraduates displays any notable differences by gender. This is considered in panels $\mathrm{B}$ and $\mathrm{C}$ of Table 5, which shows gender-specific changes over time. There is some evidence that the trends differ by gender, with there being a bigger rise in the postgraduate/undergraduate differential for women (of 0.099 as compared to $0.039 \log$ points for men). The faster increase in the differential occurs because of a faster increase in the postgraduate wage differential of 0.100 for women compared 0.044 for men. The undergraduate wage differentials did not change for either men or women (where both changes are very small and insignificantly different from

\footnotetext{
${ }^{9}$ Thus, the post-1996 experience is different to the 1980s, which was the period where wage inequality rose fastest in the UK, and where the graduate wage differential rose significantly (see Machin, 2011, or Walker and Zhu, 2008).
} 
zero). The lack of growth is probably not surprising given the very rapid increases in the supply of graduates (especially women) documented in the previous section of the paper. ${ }^{10}$

However, it turns out that the gender differences for all 26-60 year olds mask different patterns of change by age cohort. This is shown in Table 6 where the 1996 and 2011 wage differentials, and the 2011-1996 change, are shown separately by two broad age cohorts, aged 26-45 and 46-60 respectively. The pattern for the younger group of graduates is now very similar across men and women, with relatively constant undergraduate wage differentials and significantly rising postgraduate wage differentials combining to form a significant rise in the postgraduate/undergraduate wage differential of $0.079 \log$ points for men and $0.092 \log$ points for women.

For the older cohorts, however, the patterns are different. Older women with postgraduate qualifications have much more sizable wage differentials in the crosssections and do just as well through time as the younger women (in fact, numerically a little better with a rise in the postgraduate/undergraduate wage differential of $0.103 \log$ points). However, for men, the postgraduate differentials for the older cohort do not rise, and the postgraduate/undergraduate wage differential actually falls by $0.046 \log$ points between 1996 and 2011.

\section{Cross-Cohort Changes in Wage Differentials by HE Groups}

We have also looked at changes in HE related wage differentials using the British cohort data. Results are presented in Table 7, which takes the same structure as Tables 5 and 6, showing cross-sectional educational wage differentials and their cross-cohort change for all cohort members in panel A, and for men and women in panels B and C.

\footnotetext{
${ }^{10}$ See also O'Leary and Sloane (2005) who report a falling wage premium to an undergraduate degree for younger women. If we look at the younger 26-35 age group in our data we also find a fall over time in the undergraduate differential (standard error) of -0.035 (0.025) for men and -0.037 (0.029) for women, compared to an increase for postgraduates of $0.073(0.039)$ for men and $0.083(0.043)$ for women.
} 
Considering first all cohort members in panel A, the results show (like the LFS) a small rise in overall undergraduate wage differentials (which go up by 0.042 log points), but that within the graduate group wages rise significantly only for the postgraduates. Thus, the postgraduate/undergraduate wage differential widens out for this comparison of similar aged cohorts through time.

The focus on specific cohorts means that comparison with the LFS is not straightforward. Our LFS analysis so far covers different age cohorts in each year. To undertake a more consistent comparison, we have therefore also tried to select specific samples from the LFS data that more closely mirror the NCDS and BCS cohort data. We do so by selecting out the same age cohorts, to the extent that we can, and estimating the same sets of wage differentials. However, we cannot perfectly match because the first year of usable LFS data with the postgraduate variable consistently defined is 1996 . Thus, we are only able to obtain data that matches the NCDS and BCS birth cohorts at a slightly older age centred on age 38 as our first year (i.e. the NCDS 1958 birth cohort are 38 in 1996). Thus we take a sample of 36-40 year olds in the 1996 LFS (i.e. those born between 1956 and 1960) to match the NCDS 1958 birth cohort and a sample of 36-40 year olds in 2008 (i.e. born in 1968 to 1972 ) to match the BCS 1970 birth cohort. $^{11}$

Reassuringly, we obtain a similar pattern of results from these cohorts. Table A1 in the Appendix shows that the overall postgraduate/undergraduate wage differential rose by a little more (0.127) in the older age 38 LFS cohort than for the younger age 33/34 NCDSBCS comparison (0.104), but the overall pattern of rising postgraduate/undergraduate wage differentials is clear. ${ }^{12}$ The same is true for men and women where the changes were

\footnotetext{
${ }^{11}$ We use the age range 36-40 (i.e. centred on age 38) to ensure sufficiently large cell sizes for the analysis. 12 The ages after 33/34 when the NCDS and BCS cohorts have been studied again are at ages 41/42 (in 1999/2000) and age 50 (in 2008) for NCDS and at age 38 (in 2008) for BCS. These survey years mean we cannot compare directly for both cohorts at the same age when they are older. We can, however, compare the age 38 BCS in 2008 with the LFS cohort aged 36 to 40 in 2008. Doing so produces similar estimates of educational wage differentials. In the LFS 2008 36-40 cohort the postgraduate/undergraduate wage
} 
also broadly similar, with an LFS cohort rise for men of 0.133 (compared to 0.084 ) and for women a rise of 0.108 (compared to 0.102 ).

\section{Postgraduate Heterogeneity}

What about variations over time in the wage differentials for different postgraduate degrees relative to an undergraduate degree only? This is considered in Table 8 where, like the earlier analysis of LFS differentials, we break the results down by age cohort. The results in the Table therefore elaborate more on the earlier results (of Table 6) showing rises in the postgraduate/undergraduate differential for younger men, but not older men, and for both younger and older women.

Consider first the results for Masters degrees, the group of postgraduates showing the faster supply increases (in Table 2 above). It is interesting that, for younger men and all women, the wage differentials for those degrees do not fall over time despite increased supply. In fact for some of these groups they rise, for example going up by 0.051 for younger men and by a huge 0.189 for older women (the latter presumably reflecting the relatively small number of older women holding a Masters degree). The Masters wage differential compared to an undergraduate degree only falls for the older men. That the majority of the Masters differentials do not fall is therefore in line with there being an increased demand for Masters degree holders compared to undergraduate only workers.

Finally, again with the exception of the older men for whom postgraduate wage premia are either constant or falling, the other three postgraduate groups also show increases in wages over time relative to undergraduates. These rises are often sizable for women, but it is also worth noting that the relative wages for a Doctorate for men show at best modest (and statistically insignificant) improvements, again despite their much lower rise in supply than the other postgraduate groups.

differential is estimated at 0.152 (with associated standard error 0.025). For the age 38 BCS cohort in 2008 this differential is estimated in a comparable way as $0.167(0.038)$. 


\section{Implications for Social Mobility}

What are the implications for social mobility of the quest for more and more education, and the associated changes in educational wage differentials? The patterns of change we have shown in the previous two sections do not make for especially good reading in this regard. It is very clear that the individuals who have done better in terms of wages are those people who have acquired higher education qualifications. In turn, the acquisition of higher qualifications has become more skewed towards people from more wealthy backgrounds. Thus, the labour market earnings trends we have described here have not only raised earnings inequality within generations, but have also hampered social mobility. It is people from already rich family backgrounds who are increasingly reaping higher rewards in the labour market from their higher qualifications.

Our findings also highlight some new features associated with this. First, there is clear heterogeneity within the graduate group who have been doing better in terms of labour market outcomes in the last thirty years or so. An interesting trend through time is that more people are acquiring postgraduate degrees and not stopping their education to enter the labour market after their undergraduate studies. This seems to be a key part of the quest for more and more education, especially the acquisition of Master's degrees. The 1980s was characterised by sharp increases in wages for undergraduates, but this seems to have dried up more recently (possibly due to increased graduate supply finally dampening down wages in the late 1990s and 2000s) and people have realised the need to get a postgraduate degree to distinguish themselves. Thus, half of the rise in educational inequality we described in section 2 is from postgraduates and they have seen the biggest wage gains across the whole education spectrum, raising wage inequality and holding back social mobility. 
Second, there is an interesting gender dimension to the patterns of change that also has ramifications for social mobility. Women's education levels were lagging some way behind men's at the start of the period we study (thirty years ago in 1981) but by 2011 they are just as high. Commensurate with this, the educational inequality numbers (in Table 4) showed that women from the top quintile of the family income distribution have benefited in terms of getting more education, but unlike men this is also true of women in the middle part of the family distribution. Thus, women's increased education has proven to be a key factor in terms of narrowing gender wage differentials through time.

The final observation on gender differences and social mobility is that, at the bottom end of the education distribution (those with no or limited qualifications), men are now doing worse than women in terms of educational attainment. This, of course, can be tracked back to school where girls are doing better, on average, across the board. The bigger share of young men leaving school with poor qualifications is a serious policy concern. Similar patterns can be seen in the US where men's education has been falling back quite rapidly relative to women. ${ }^{13}$ Autor (2010) argues that stagnating male education levels imply serious problems because men are behind at the bottom end of the education spectrum and the labour market increasingly penalises this, he also argues that there are wider negative consequences, including crime, lower marriage probabilities (as there are fewer similarly educated women) and the societal problems that ensue.

\section{Concluding Remarks}

In this paper, we consider how the quest for more and more education in Britain has raised labour market inequality within generations and acted to hinder social mobility across generations. We use evidence from the Labour Force Survey and the British cohort studies

\footnotetext{
${ }^{13}$ See Bailey and Dynarski (2011) who note this trend in gender education gaps and who like our British results, show that there are growing gaps in college entry and completion between individuals from high and low income families.
} 
to document how educational attainment has changed through time and how the labour market has changed the way it rewards workers with different education levels. On the former, we document a very rapid educational upgrading that has occurred in the past thirty years or so. On the latter, we see sizable increases in relative wages for workers with higher education levels, despite their rapid increases in relative supply.

Increased qualification attainment has, however, not been neutral across the family income distribution. Indeed, people from richer backgrounds have done much better in terms of educational upgrading than those from poorer backgrounds. At the same time, because of labour market changes favouring more educated workers (e.g. due to technical changes), wage differentials for the more educated have risen. If these two facts (more education for people from richer backgrounds and an increase in the payoff to this education) are put together, then the overall result has been increases in within generation inequalities and, by reinforcing already existent inequalities from the previous generation, falling social mobility. Of course, these findings are specific to the cohorts of individuals and time periods that we have studied.

We have also noted three important features of these patterns of change which existing research has not studied in the context of social mobility. First, the pattern of educational upgrading has resulted in a rise in the number of people acquiring postgraduate qualifications. Moreover, it is these qualifications, rather than undergraduate degrees only, that have commanded the biggest increase in wage differentials compared to other workers. Second, women have narrowed education gaps between themselves and men over the last thirty years and in Britain by 2011 male-female education gaps have converged. If men and women are more likely to choose partners with similar educational attainment this is potentially a further detriment to household income inequality and to social mobility. Third, the faster accumulation of qualifications for women then for men 
over time has left some men behind, especially at the bottom of the education distribution where labour market prospects and opportunities have been worsening through time. 


\section{References}

Acemoglu, D. and D. Autor (2010) Skills, Tasks and Technologies: Implications for Employment and Earnings, in Ashenfelter, O. and D. Card (eds.) Handbook of Labor Economics Volume 4, Amsterdam: Elsevier.

Autor, D. (2010) US Labor Market Challenges Over the Longer Term, MIT mimeo.

Bailey, M. and S. Dynarksi (2011) Gains and Gaps: Changing Inequality in US College Entry and Completion, National Bureau of Economic Research Working Paper No. 17633.

Belley, P. and L. Lochner (2007) The Changing Role of Family Income and Ability in Determining Educational Achievement, Journal of Human Capital, 1, 37-89.

Blanden, J., A. Goodman, P. Gregg and S. Machin (2005) Changes in Intergenerational Income Mobility in Britain, in M. Corak (ed.), Generational Income Mobility in North America and Europe, Cambridge, MA.: Cambridge University Press.

Blanden, J., P. Gregg and L. Macmillan (2007) Accounting for Intergenerational Income Persistence: Noncognitive Skills, Ability and Education, Economic Journal, 117, C43-C60.

Blanden, J., P. Gregg and L. Macmillan (2011) Intergenerational Persistence in Income and Social Class: The Impact of Within-Group Inequality, IZA Discussion Paper No. 6202.

Blanden, J. and S. Machin (2004) Inequality in the Expansion of Higher Education, Scottish Journal of Political Economy, Special Issue on Education, 51, 230-249.

Blanden, J. and S. Machin (2008) Up and Down the Generational Income Ladder in Britain: Past Changes and Future Prospects, National Institute Economic Review, 205, 101-116

Eriksson, R. and J. Goldthorpe (2010) Has Social Mobility Decreased? Reconciling Divergent Findings on Income and Class Mobility' British Journal of Sociology, 61, 211-30.

Ermisch, J. and C. Nicoletti (2007) Intergenerational Earnings Mobility: Changes Across Cohorts in Britain, B.E. Journal of Economic Analysis and Policy, 7, Issue 2 (Contributions) Article 9.

Gregg, P. and L. Macmillan (2010) Family Income, Education and Cognitive Ability in the Next Generation: Exploring Income Gradients in Education and Test Scores for Current Cohorts of Youth, Longitudinal and Life Course Studies, 1, 259-80.

Lindley, J. and S. Machin (2011) Postgraduate Education and Rising Wage Inequality, Centre for Economic Performance Discussion Paper No. 984 and IZA Discussion Paper No. 5981. 
Machin, S. (2011) Changes in UK Wage Inequality Over the Last Forty Years, in P. Gregg and J. Wadsworth (eds.) The Labour Market in Winter, Oxford University Press,

O'Leary, N. and P. Sloane (2005) The Changing Wage Return to an Undergraduate Education, IZA Discussion Paper No. 1549.

Walker, I. and Y. Zhu (2008) The College Wage Premium and the Expansion of Higher Education in the UK, Scandinavian Journal of Economics, 110, 695-709. 
Figure 1: Trends in Higher Education Participation in Great Britain, 1981-2009

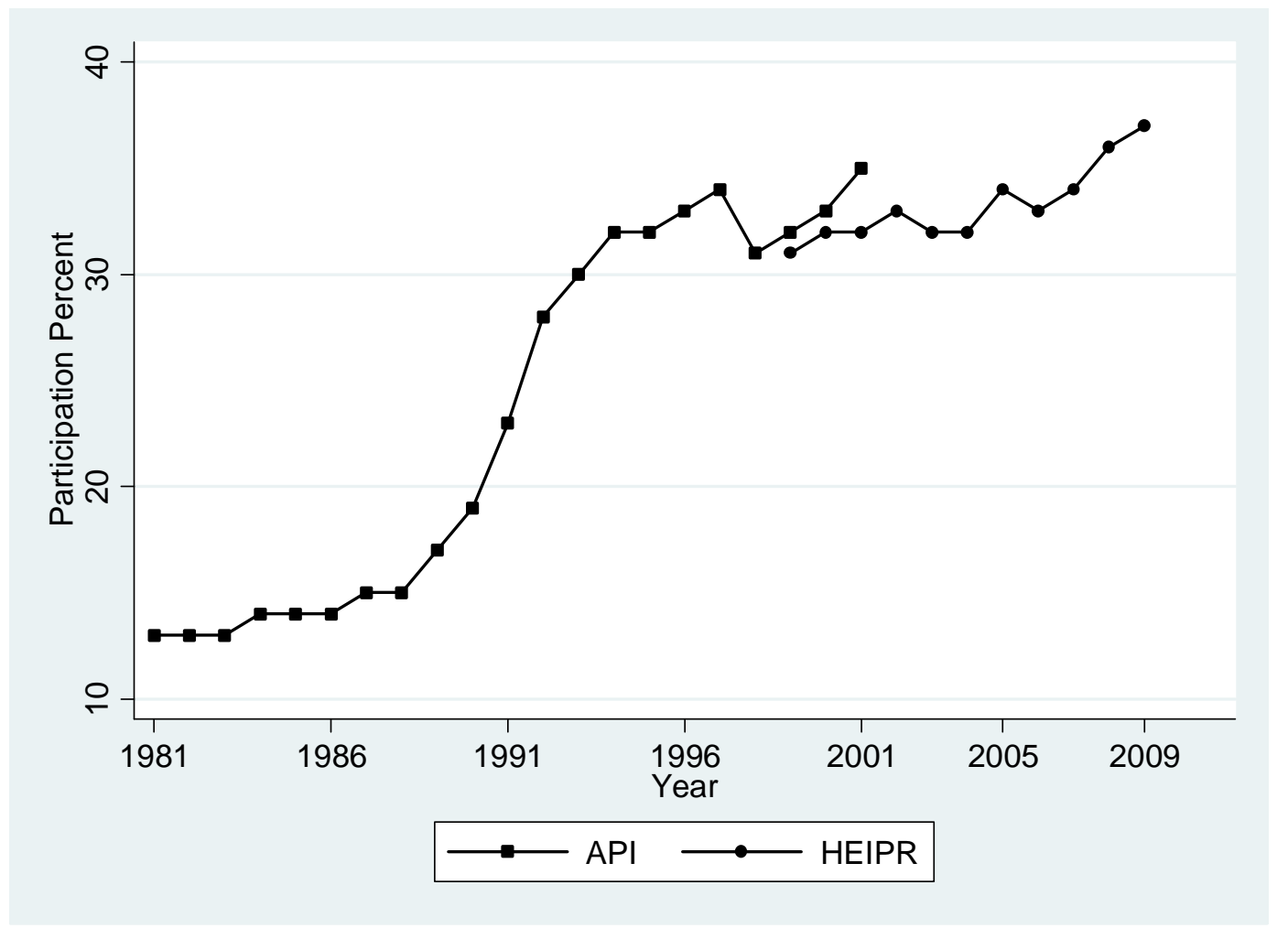

Notes: The Age Participation Index (API) is the number of domiciled young people (aged less than 21) who are initial entrants to full time and sandwich undergraduate courses as a percentage of the 18 to 19 year old GB population. The API was discontinued in 2001 and replaced by the Higher Education Initial Participation Rate (HEIPR), which has a different definition as it covers entrants to HE from different age groups (for the one reported here covering ages 17 to 20). 
Figure 2:

Trends in the Overall Postgraduate/Undergraduate Only

Wage Differential, 1996-2011

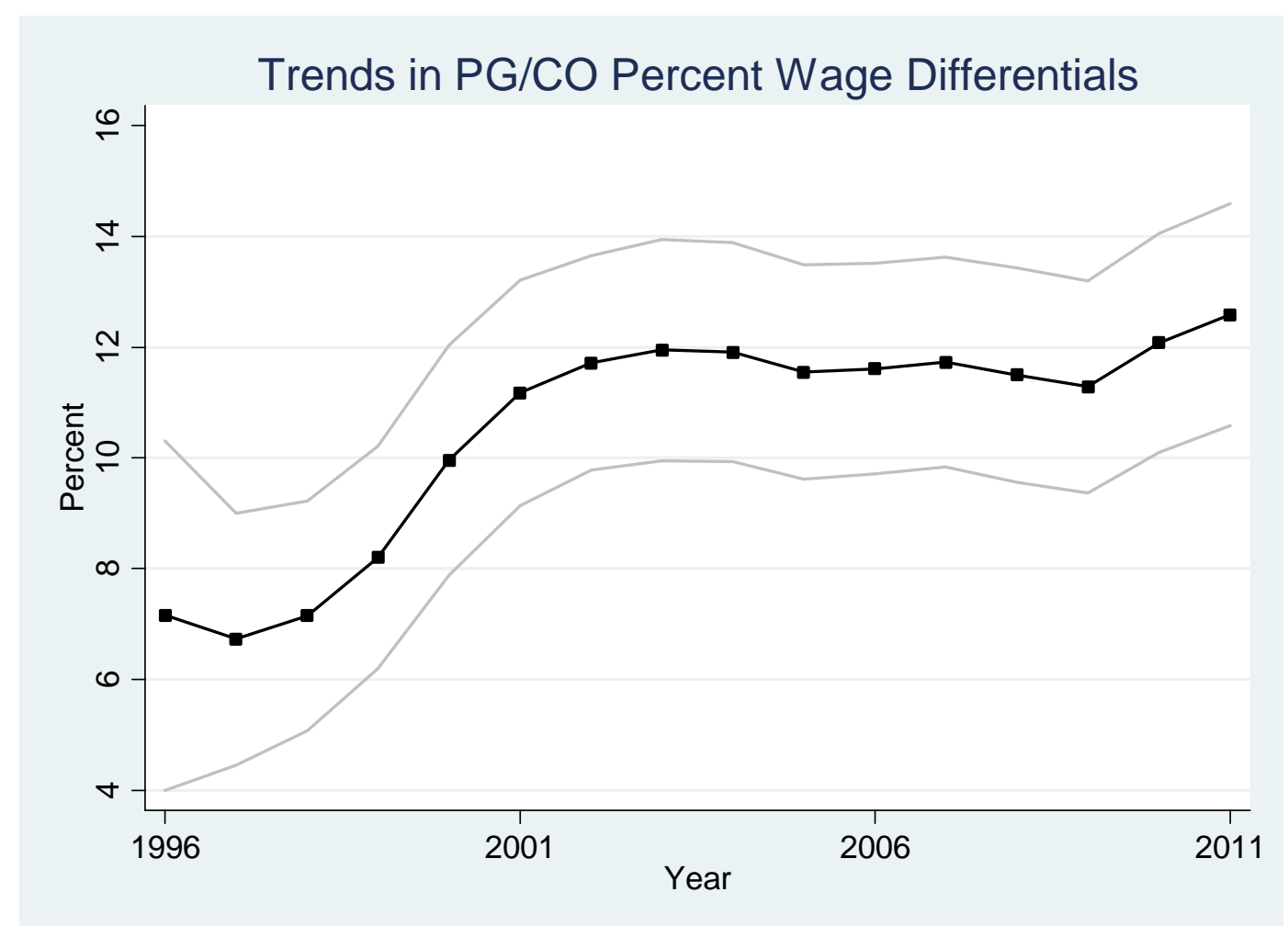

Notes: The squares joined by the dark line show three year moving averages of the postgraduate/undergraduate wage differential, derived from annual estimates of the log earnings equations for all full-time workers reported in panel A of Table 5 and calculated as $[\exp (\beta)-1] \mathrm{X} 100$, where $\beta$ is the estimated postgraduate/undergraduate only log earnings differential. The solid lighter lines are $95 \%$ confidence intervals. 
Table 1: Employment Shares by Education

\begin{tabular}{|c|c|c|c|c|c|c|c|}
\hline A. All & 1981 & 1986 & 1991 & 1996 & 2001 & 2006 & 2011 \\
\hline No Qualifications & 0.58 & 0.47 & 0.33 & 0.16 & 0.11 & 0.08 & 0.05 \\
\hline Intermediate A & 0.23 & 0.29 & 0.43 & 0.53 & 0.55 & 0.53 & 0.52 \\
\hline Intermediate B & 0.14 & 0.16 & 0.15 & 0.17 & 0.16 & 0.15 & 0.12 \\
\hline $\begin{array}{l}\text { Undergraduate Degree or Higher } \\
\text { Of which: }\end{array}$ & 0.05 & 0.07 & 0.09 & 0.14 & 0.18 & 0.23 & 0.31 \\
\hline Undergraduate Degree Only & - & - & - & 0.10 & 0.12 & 0.15 & 0.20 \\
\hline Postgraduate Degree & - & - & - & 0.04 & 0.06 & 0.08 & 0.11 \\
\hline Sample Size & 96384 & 69861 & 69998 & 172024 & 163714 & 148705 & 121246 \\
\hline B. Men & 1981 & 1986 & 1991 & 1996 & 2001 & 2006 & 2011 \\
\hline No Qualifications & 0.55 & 0.44 & 0.27 & 0.12 & 0.10 & 0.08 & 0.05 \\
\hline Intermediate A & 0.25 & 0.32 & 0.48 & 0.57 & 0.57 & 0.54 & 0.53 \\
\hline Intermediate B & 0.13 & 0.15 & 0.14 & 0.15 & 0.14 & 0.14 & 0.11 \\
\hline $\begin{array}{l}\text { Undergraduate Degree or Higher } \\
\text { Of which: }\end{array}$ & 0.07 & 0.09 & 0.11 & 0.16 & 0.19 & 0.24 & 0.31 \\
\hline Undergraduate Degree Only & - & - & - & 0.11 & 0.13 & 0.15 & 0.20 \\
\hline Postgraduate Degree & - & - & - & 0.05 & 0.06 & 0.09 & 0.10 \\
\hline Sample Size & 47680 & 35131 & 35143 & 86232 & 81339 & 72654 & 58324 \\
\hline C. Women & 1981 & 1986 & 1991 & 1996 & 2001 & 2006 & 2011 \\
\hline No Qualifications & 0.62 & 0.51 & 0.39 & 0.20 & 0.13 & 0.09 & 0.05 \\
\hline Intermediate $\mathrm{A}$ & 0.20 & 0.27 & 0.37 & 0.49 & 0.53 & 0.52 & 0.51 \\
\hline Intermediate B & 0.15 & 0.18 & 0.17 & 0.19 & 0.18 & 0.17 & 0.13 \\
\hline $\begin{array}{l}\text { Undergraduate Degree or Higher } \\
\text { Of which: }\end{array}$ & 0.03 & 0.05 & 0.07 & 0.11 & 0.16 & 0.22 & 0.30 \\
\hline Undergraduate Degree Only & - & - & - & 0.08 & 0.11 & 0.15 & 0.20 \\
\hline Postgraduate Degree & - & - & - & 0.03 & 0.05 & 0.08 & 0.10 \\
\hline Sample Size & 48704 & 34730 & 34855 & 85792 & 82375 & 76051 & 62922 \\
\hline
\end{tabular}

Notes: Source is Labour Force Surveys (annual for 1981, 1986 and 1991, quarterly thereafter) for people in Great Britain. Employment shares are defined for people in work aged 26 to 60. Intermediate A qualifications include school-level qualification up to and including A levels (or an equivalent level diploma via further education), whilst intermediate B include professional undergraduate level qualifications which are not a degree (like teaching and nursing qualifications). 
Table 2 : Employment Shares of Postgraduates

\begin{tabular}{|c|c|c|c|c|}
\hline A. All & 1996 & 2001 & 2006 & 2011 \\
\hline Masters & 0.45 & 0.49 & 0.51 & 0.52 \\
\hline PGCE & 0.21 & 0.21 & 0.23 & 0.23 \\
\hline Doctorate & 0.19 & 0.16 & 0.14 & 0.13 \\
\hline Other Postgraduate & 0.15 & 0.13 & 0.12 & 0.12 \\
\hline Sample Size & 6898 & 8980 & 11928 & 11778 \\
\hline B. Men & 1996 & 2001 & 2006 & 2011 \\
\hline Masters & 0.48 & 0.55 & 0.55 & 0.58 \\
\hline PGCE & 0.14 & 0.13 & 0.14 & 0.15 \\
\hline Doctorate & 0.23 & 0.19 & 0.18 & 0.16 \\
\hline Other Postgraduate & 0.14 & 0.13 & 0.12 & 0.11 \\
\hline Sample Size & 4133 & 5056 & 6214 & 5591 \\
\hline C. Women & 1996 & 2001 & 2006 & 2011 \\
\hline Masters & 0.40 & 0.42 & 0.45 & 0.45 \\
\hline PGCE & 0.32 & 0.32 & 0.33 & 0.32 \\
\hline Doctorate & 0.11 & 0.12 & 0.10 & 0.09 \\
\hline Other Postgraduate & 0.16 & 0.14 & 0.12 & 0.14 \\
\hline Sample Size & 2765 & 3924 & 5714 & 6187 \\
\hline
\end{tabular}

Notes: Source is Quarterly Labour Force Surveys (1996, 2001, 2006 and 2011) for people in Great Britain. Employment shares are defined for postgraduates in work aged 26 to 60 . 
Table 3: Qualification Attainment (by Age 33/34) and Family Income, British Birth Cohorts

\begin{tabular}{|c|c|c|c|c|c|c|}
\hline & \multicolumn{3}{|c|}{1958 Birth Cohort, NCDS (in 1991) } & \multicolumn{3}{|c|}{1970 Birth Cohort, BCS (in 2004) } \\
\hline & $\begin{array}{c}\text { Lowest } 20 \\
\text { Percent }\end{array}$ & $\begin{array}{c}\text { Middle } 60 \\
\text { Percent }\end{array}$ & $\begin{array}{c}\text { Highest } 20 \\
\text { Percent }\end{array}$ & $\begin{array}{c}\text { Lowest } 20 \\
\text { Percent }\end{array}$ & $\begin{array}{c}\text { Middle } 60 \\
\text { Percent }\end{array}$ & $\begin{array}{c}\text { Highest } 20 \\
\text { Percent }\end{array}$ \\
\hline $\begin{array}{l}\text { A. All } \\
\text { a) } \operatorname{Pr}[\text { No Qualifications] } \\
\text { b) } \operatorname{Pr}[\text { Intermediate A] } \\
\text { c) } \operatorname{Pr}[\text { Intermediate B] } \\
\text { d) } \operatorname{Pr}[\text { Undergraduate Degree or Higher] }\end{array}$ & $\begin{array}{l}0.14 \\
0.61 \\
0.16 \\
0.09\end{array}$ & $\begin{array}{l}0.08 \\
0.63 \\
0.17 \\
0.12\end{array}$ & $\begin{array}{l}0.04 \\
0.49 \\
0.19 \\
0.28\end{array}$ & $\begin{array}{l}0.12 \\
0.63 \\
0.15 \\
0.10\end{array}$ & $\begin{array}{l}0.04 \\
0.59 \\
0.16 \\
0.21\end{array}$ & $\begin{array}{l}0.01 \\
0.39 \\
0.22 \\
0.37\end{array}$ \\
\hline $\begin{array}{l}\text { B. Men } \\
\text { a) } \operatorname{Pr}[\text { No Qualifications }] \\
\text { b) } \operatorname{Pr}[\text { Intermediate A] } \\
\text { c) } \operatorname{Pr}[\text { Intermediate B] } \\
\text { d) } \operatorname{Pr}[\text { Undergraduate Degree or Higher] }\end{array}$ & $\begin{array}{l}0.12 \\
0.62 \\
0.17 \\
0.10\end{array}$ & $\begin{array}{l}0.08 \\
0.61 \\
0.16 \\
0.15\end{array}$ & $\begin{array}{l}0.03 \\
0.50 \\
0.17 \\
0.30\end{array}$ & $\begin{array}{l}0.15 \\
0.63 \\
0.13 \\
0.10\end{array}$ & $\begin{array}{l}0.06 \\
0.60 \\
0.16 \\
0.18\end{array}$ & $\begin{array}{l}0.01 \\
0.40 \\
0.23 \\
0.38\end{array}$ \\
\hline $\begin{array}{l}\text { C. Women } \\
\text { a) } \operatorname{Pr}[\text { No Qualifications] } \\
\text { b) } \operatorname{Pr}[\text { Intermediate A] } \\
\text { c) } \operatorname{Pr}[\text { Intermediate B] } \\
\text { d) } \operatorname{Pr} \text { [Undergraduate Degree or Higher] }\end{array}$ & $\begin{array}{l}0.17 \\
0.60 \\
0.14 \\
0.09\end{array}$ & $\begin{array}{l}0.09 \\
0.66 \\
0.17 \\
0.08\end{array}$ & $\begin{array}{l}0.06 \\
0.47 \\
0.22 \\
0.26\end{array}$ & $\begin{array}{l}0.09 \\
0.62 \\
0.18 \\
0.12\end{array}$ & $\begin{array}{l}0.03 \\
0.58 \\
0.17 \\
0.23\end{array}$ & $\begin{array}{l}0.01 \\
0.38 \\
0.24 \\
0.36\end{array}$ \\
\hline
\end{tabular}

Notes: Sample sizes are All - NCDS 3875, BCS 3238; Men - NCDS 2109, BCS 1598; Women - NCDS 1766, BCS 1640. Intermediate A qualifications include school-level qualification up to and including A levels (or an equivalent level diploma via further education), whilst intermediate B include professional undergraduate level qualifications which are not a degree (like teaching and nursing qualifications). 
Table 4: HE Qualification Attainment (by Age 33/34) and Family Income, British Birth Cohorts

\begin{tabular}{|c|c|c|c|c|c|c|c|c|c|}
\hline & \multicolumn{4}{|c|}{1958 Birth Cohort, NCDS (in 1991) } & \multicolumn{4}{|c|}{1970 Birth Cohort, BCS (in 2004) } & \multirow{2}{*}{$\begin{array}{c}\text { Cross-Cohort Change } \\
\text { HE } \\
\text { Inequality }\end{array}$} \\
\hline & $\begin{array}{c}\text { Lowest } 20 \\
\text { Percent }\end{array}$ & $\begin{array}{c}\text { Middle } 60 \\
\text { Percent }\end{array}$ & $\begin{array}{c}\text { Highest } 20 \\
\text { Percent }\end{array}$ & $\begin{array}{c}\mathrm{HE} \\
\text { Inequality }\end{array}$ & $\begin{array}{c}\text { Lowest } 20 \\
\text { Percent }\end{array}$ & $\begin{array}{c}\text { Middle } 60 \\
\text { Percent }\end{array}$ & $\begin{array}{c}\text { Highest } 20 \\
\text { Percent }\end{array}$ & $\begin{array}{c}\mathrm{HE} \\
\text { Inequality }\end{array}$ & \\
\hline $\begin{array}{l}\text { A. All } \\
\text { a) } \operatorname{Pr}[\text { Degree }] \\
\text { b) } \operatorname{Pr}[\text { Undergraduate Degree }] \\
\text { c) } \operatorname{Pr}[\text { Postgraduate Degree }]\end{array}$ & $\begin{array}{l}0.09 \\
0.07 \\
0.02\end{array}$ & $\begin{array}{l}0.12 \\
0.09 \\
0.03\end{array}$ & $\begin{array}{l}0.28 \\
0.20 \\
0.08\end{array}$ & $\begin{array}{l}0.19(0.02) \\
0.13(0.02) \\
0.06(0.01)\end{array}$ & $\begin{array}{l}0.10 \\
0.07 \\
0.03\end{array}$ & $\begin{array}{l}0.21 \\
0.14 \\
0.07\end{array}$ & $\begin{array}{l}0.37 \\
0.24 \\
0.13\end{array}$ & $\begin{array}{l}0.27(0.02) \\
0.17(0.02) \\
0.10(0.01)\end{array}$ & $\begin{array}{l}0.08(0.03) \\
0.04(0.03) \\
0.04(0.02)\end{array}$ \\
\hline $\begin{array}{l}\text { B. Men } \\
\text { a) } \operatorname{Pr}[\text { Degree }] \\
\text { b) } \operatorname{Pr}[\text { Undergraduate Degree }] \\
\text { c) } \operatorname{Pr}[\text { Postgraduate Degree] }\end{array}$ & $\begin{array}{l}0.10 \\
0.08 \\
0.02\end{array}$ & $\begin{array}{l}0.15 \\
0.11 \\
0.04\end{array}$ & $\begin{array}{l}0.30 \\
0.22 \\
0.08\end{array}$ & $\begin{array}{l}0.20(0.03) \\
0.14(0.02) \\
0.06(0.02)\end{array}$ & $\begin{array}{l}0.10 \\
0.07 \\
0.03\end{array}$ & $\begin{array}{l}0.18 \\
0.13 \\
0.06\end{array}$ & $\begin{array}{l}0.38 \\
0.24 \\
0.15\end{array}$ & $\begin{array}{l}0.28(0.03) \\
0.17(0.03) \\
0.12(0.02)\end{array}$ & $\begin{array}{l}0.08(0.04) \\
0.03(0.04) \\
0.06(0.03)\end{array}$ \\
\hline $\begin{array}{l}\text { C. Women } \\
\text { a) } \operatorname{Pr}[\text { Degree }] \\
\text { b) } \operatorname{Pr}[\text { Undergraduate Degree] } \\
\text { c) } \operatorname{Pr}[\text { Postgraduate Degree] }\end{array}$ & $\begin{array}{l}0.09 \\
0.06 \\
0.02\end{array}$ & $\begin{array}{l}0.08 \\
0.06 \\
0.02\end{array}$ & $\begin{array}{l}0.26 \\
0.18 \\
0.07\end{array}$ & $\begin{array}{l}0.17(0.03) \\
0.12(0.02) \\
0.05(0.02)\end{array}$ & $\begin{array}{l}0.12 \\
0.08 \\
0.04\end{array}$ & $\begin{array}{l}0.23 \\
0.14 \\
0.08\end{array}$ & $\begin{array}{l}0.36 \\
0.25 \\
0.12\end{array}$ & $\begin{array}{l}0.24(0.03) \\
0.17(0.03) \\
0.08(0.02)\end{array}$ & $\begin{array}{l}0.07(0.04) \\
0.05(0.04) \\
0.03(0.04)\end{array}$ \\
\hline
\end{tabular}

Notes: Sample sizes are All - NCDS 3875, BCS 3238; Men - NCDS 2109, BCS 1598; Women - NCDS 1766, BCS 1640. Standard errors in parentheses. 
Table 5: LFS Wage Differentials for HE Groups (Full-Timers)

\begin{tabular}{|c|c|c|c|c|c|}
\hline A. All & 1996 & 2001 & 2006 & 2011 & Change 2011-1996 \\
\hline Undergraduate Degree or Higher & $0.428(0.009)$ & $0.458(0.006)$ & $0.457(0.006)$ & $0.457(0.006)$ & $0.029(0.012)$ \\
\hline Undergraduate Degree Only & $0.409(0.010)$ & $0.425(0.007)$ & $0.416(0.007)$ & $0.416(0.007)$ & $0.006(0.013)$ \\
\hline Postgraduate Degree & $0.470(0.014)$ & $0.531(0.009)$ & $0.527(0.008)$ & $0.545(0.009)$ & $0.075(0.018)$ \\
\hline Postgraduate/Undergraduate & $0.060(0.016)$ & $0.106(0.010)$ & $0.111(0.009)$ & $0.129(0.010)$ & $0.068(0.021)$ \\
\hline Sample size & 21300 & 38007 & 33032 & 26285 & \\
\hline B. Men & 1996 & 2001 & 2006 & 2011 & \\
\hline Undergraduate Degree or Higher & $0.401(0.011)$ & $0.427(0.007)$ & $0.415(0.008)$ & $0.419(0.008)$ & $0.018(0.015)$ \\
\hline Undergraduate Degree Only & $0.378(0.012)$ & $0.391(0.009)$ & $0.377(0.009)$ & $0.383(0.010)$ & $0.005(0.017)$ \\
\hline Postgraduate Degree & $0.452(0.018)$ & $0.505(0.012)$ & $0.482(0.011)$ & $0.496(0.013)$ & $0.044(0.024)$ \\
\hline Postgraduate/Undergraduate & $0.074(0.020)$ & $0.113(0.014)$ & $0.104(0.013)$ & $0.113(0.014)$ & $0.039(0.027)$ \\
\hline Sample size & 13621 & 23594 & 19734 & 15509 & \\
\hline C. Women & 1996 & 2001 & 2006 & 2011 & \\
\hline Undergraduate Degree or Higher & $0.474(0.014)$ & $0.510(0.009)$ & $0.515(0.009)$ & $0.510(0.004)$ & $0.035(0.019)$ \\
\hline Undergraduate Degree Only & $0.458(0.015)$ & $0.479(0.010)$ & $0.469(0.010)$ & $0.459(0.011)$ & $0.001(0.021)$ \\
\hline Postgraduate Degree & $0.512(0.022)$ & $0.577(0.014)$ & $0.595(0.012)$ & $0.612(0.014)$ & $0.100(0.029)$ \\
\hline Postgraduate/Undergraduate & $0.054(0.025)$ & $0.098(0.015)$ & $0.126(0.014)$ & $0.153(0.014)$ & $0.099(0.032)$ \\
\hline Sample size & 7679 & 14413 & 13298 & 10776 & \\
\hline
\end{tabular}

Notes: The sample consists of full-time workers aged 26 to 60 in Britain Wage differentials are relative to Intermediate A qualifications. Control variables included are: age, age squared, no qualifications, intermediate B, white, private sector, married/cohabiting, government office region dummies and additionally gender in the All specification. Standard errors are in parentheses. 
Table 6: LFS Wage Differentials for HE Groups (Full-Timers) by Age Cohort

\begin{tabular}{|c|c|c|c|c|c|c|}
\hline \multirow[b]{2}{*}{ A. Men } & \multicolumn{3}{|c|}{ Age 26-45 } & \multicolumn{3}{|c|}{ Age 46-60 } \\
\hline & 1996 & 2011 & Change 2011-1996 & 1996 & 2011 & Change 2011-1996 \\
\hline Undergraduate Degree or Higher & $0.371(0.012)$ & $0.390(0.010)$ & $0.019(0.017)$ & $0.482(0.022)$ & $0.478(0.015)$ & $-0.004(0.029)$ \\
\hline Undergraduate Degree Only & $0.361(0.014)$ & $0.356(0.012)$ & $-0.005(0.020)$ & $0.428(0.026)$ & $0.442(0.017)$ & $0.014(0.034)$ \\
\hline Postgraduate Degree & $0.396(0.021)$ & $0.470(0.016)$ & $0.074(0.028)$ & $0.574(0.033)$ & $0.542(0.022)$ & $-0.032(0.043)$ \\
\hline Postgraduate/Undergraduate & $0.035(0.024)$ & $0.114(0.017)$ & $0.079(0.032)$ & $0.146(0.039)$ & $0.100(0.025)$ & $-0.046(0.051)$ \\
\hline Sample size & 9031 & 9155 & & 4590 & 6354 & \\
\hline B. Women & 1996 & 2011 & Change 2011-1996 & 1996 & 2011 & Change 2011-1996 \\
\hline Undergraduate Degree or Higher & $0.464(0.016)$ & $0.477(0.012)$ & $0.013(0.022)$ & $0.521(0.028)$ & $0.566(0.016)$ & $0.045(0.037)$ \\
\hline Undergraduate Degree Only & $0.456(0.026)$ & $0.441(0.014)$ & $-0.016(0.024)$ & $0.475(0.034)$ & $0.480(0.022)$ & $0.005(0.044)$ \\
\hline Postgraduate Degree & $0.486(0.026)$ & $0.562(0.018)$ & $0.076(0.035)$ & $0.596(0.042)$ & $0.704(0.022)$ & $0.108(0.053)$ \\
\hline Postgraduate/Undergraduate & $0.029(0.029)$ & $0.122(0.018)$ & $0.092(0.038)$ & $0.121(0.050)$ & $0.223(0.026)$ & $0.103(0.063)$ \\
\hline Sample size & 5170 & 6207 & & 2509 & 4569 & \\
\hline
\end{tabular}

Notes: The samples consist of full-time workers aged 26 to 45 and 46 to 60 in Britain Wage differentials are relative to Intermediate A qualifications. Control variables included are: age, age squared,, no qualifications, intermediate B, white, private sector, married/cohabiting and government office region dummies. Standard errors are in parentheses. 
Table 7: Cross-Cohort Wage Differentials for HE Groups (Full-Timers)

\begin{tabular}{|c|c|c|c|}
\hline A. All & NCDS, 1991, Age 33 & BCS, 2004, Age 34 & Cross-Cohort Change \\
\hline Undergraduate Degree or Higher & $0.403(0.021)$ & $0.445(0.022)$ & $0.042(0.030)$ \\
\hline Undergraduate Degree Only & $0.409(0.024)$ & $0.416(0.026)$ & $0.007(0.035)$ \\
\hline Postgraduate Degree & $0.388(0.036)$ & $0.498(0.032)$ & $0.111(0.049)$ \\
\hline Postgraduate/Undergraduate & $-0.021(0.040)$ & $0.082(0.037)$ & $0.104(0.055)$ \\
\hline Sample size & 5335 & 5028 & \\
\hline B. Men & NCDS, 1991, Age 33 & BCS, 2004, Age 34 & Cross-Cohort Change \\
\hline Undergraduate Degree or Higher & $0.364(0.025)$ & $0.425(0.027)$ & $0.060(0.037)$ \\
\hline Undergraduate Degree Only & $0.378(0.029)$ & $0.413(0.032)$ & $0.035(0.042)$ \\
\hline Postgraduate Degree & $0.329(0.043)$ & $0.448(0.041)$ & $0.118(0.059)$ \\
\hline Postgraduate/Undergraduate & $-0.049(0.048)$ & $0.035(0.048)$ & $0.084(0.068)$ \\
\hline Sample size & 3645 & 3247 & \\
\hline C. Women & NCDS, 1991, Age 33 & BCS, 2004, Age 34 & Cross-Cohort Change \\
\hline Undergraduate Degree or Higher & $0.458(0.038)$ & $0.465(0.038)$ & $0.007(0.054)$ \\
\hline Undergraduate Degree Only & $0.450(0.043)$ & $0.416(0.044)$ & $-0.033(0.061)$ \\
\hline Postgraduate Degree & $0.480(0.063)$ & $0.550(0.053)$ & $0.069(0.084)$ \\
\hline Postgraduate/Undergraduate & $0.031(0.070)$ & $0.133(0.060)$ & $0.102(0.094)$ \\
\hline Sample size & 1690 & 1781 & \\
\hline
\end{tabular}

Notes: Wage differentials are relative to intermediate A qualifications. Control variables included are: no qualifications, intermediate B, white, private sector, married/cohabiting, government office region dummies and additionally gender in the All specification. Standard errors are in parentheses. 
Table 8: LFS Wage Differentials by Postgraduate Group (Full-Timers) by Age Cohort

\begin{tabular}{|c|c|c|c|c|c|c|}
\hline \multirow[b]{2}{*}{ A. Men } & \multicolumn{3}{|c|}{ Age 26-45 } & \multicolumn{3}{|c|}{ Age 46-60 } \\
\hline & 1996 & 2011 & Change 2011-1996 & 1996 & 2011 & Change 2011-1996 \\
\hline Master Degree & $0.095(0.031)$ & $0.145(0.021)$ & $0.051(0.045)$ & $0.169(0.053)$ & $0.096(0.035)$ & $-0.073(0.075)$ \\
\hline PGCE & $-0.084(0.050)$ & $0.016(0.039)$ & $0.101(0.075)$ & $0.044(0.117)$ & $-0.059(0.065)$ & $-0.104(0.159)$ \\
\hline Doctorate & $0.097(0.043)$ & $0.131(0.038)$ & $0.033(0.066)$ & $0.239(0.066)$ & $0.239(0.051)$ & $-0.0002(0.096)$ \\
\hline Other Postgraduate & $0.025(0.047)$ & $0.138(0.045)$ & $0.113(0.075)$ & $0.111(0.086)$ & $0.153(0.067)$ & $0.042(0.126)$ \\
\hline Sample size & 1587 & 3229 & & 594 & 1512 & \\
\hline B. Women & 1996 & 2011 & Change 2011-1996 & 1996 & 2011 & Change 2011-1996 \\
\hline Master Degree & $0.123(0.041)$ & $0.125(0.024)$ & $0.002(0.059)$ & $0.110(0.072)$ & $0.299(0.036)$ & $0.189(0.095)$ \\
\hline PGCE & $-0.056(0.044)$ & $0.052(0.029)$ & $0.108(0.065)$ & $-0.051(0.086)$ & $0.095(0.041)$ & $0.146(0.113)$ \\
\hline Doctorate & $0.053(0.074)$ & $0.230(0.044)$ & $0.177(0.106)$ & $0.304(0.107)$ & $0.408(0.072)$ & $0.104(0.148)$ \\
\hline Other Postgraduate & $0.065(0.053)$ & $0.140(0.040)$ & $0.075(0.079)$ & $0.025(0.136)$ & $0.180(0.060)$ & $0.155(0.177)$ \\
\hline Sample size & 973 & 2700 & & 282 & 1141 & \\
\hline
\end{tabular}

Notes: The samples consist of full-time graduate workers aged 26 to 45 and 46 to 60 in Britain Wage differentials are relative to Undergraduate Degree Only. Control variables included are: age, age squared, white, private sector, married/cohabiting, government office region dummies. Standard errors are in parentheses. 


\section{Appendix}

Table A1: LFS Cross-Cohort Wage Differentials for HE Groups (Full-Timers)

\begin{tabular}{|c|c|c|c|}
\hline A. All & $\begin{array}{c}\text { Born 1956-60, } \\
\text { Age } 36-40 \text { in } 1996\end{array}$ & $\begin{array}{c}\text { Born } 1968-72, \\
\text { Age } 36-40 \text { in } 2008\end{array}$ & Cross-Cohort Change \\
\hline Undergraduate Degree or Higher & $0.440(0.021)$ & $0.493(0.016)$ & $0.053(0.028)$ \\
\hline Undergraduate Degree Only & $0.433(0.024)$ & $0.438(0.018)$ & $0.004(0.032)$ \\
\hline Postgraduate Degree & $0.458(0.034)$ & $0.590(0.022)$ & $0.132(0.044)$ \\
\hline Postgraduate/Undergraduate & $0.025(0.039)$ & $0.152(0.025)$ & $0.127(0.050)$ \\
\hline Sample size & 3446 & 5010 & \\
\hline B. Men & $\begin{array}{c}\text { Born } 1956-60, \\
\text { Age } 36-40 \text { in } 1996\end{array}$ & $\begin{array}{c}\text { Born } 1968-72, \\
\text { Age } 36-40 \text { in } 2008\end{array}$ & Cross-Cohort Change \\
\hline Undergraduate Degree or Higher & $0.395(0.025)$ & $0.435(0.020)$ & $0.039(0.035)$ \\
\hline Undergraduate Degree Only & $0.384(0.029)$ & $0.373(0.024)$ & $-0.010(0.040)$ \\
\hline Postgraduate Degree & $0.422(0.042)$ & $0.545(0.029)$ & $0.123(0.056)$ \\
\hline Postgraduate/Undergraduate & $0.039(0.048)$ & $0.172(0.034)$ & $0.133(0.063)$ \\
\hline Sample size & 2306 & 3093 & \\
\hline C. Women & $\begin{array}{c}\text { Born } 1956-60, \\
\text { Age } 36-40 \text { in } 1996\end{array}$ & $\begin{array}{c}\text { Born } 1968-72, \\
\text { Age } 36-40 \text { in } 2008\end{array}$ & Cross-Cohort Change \\
\hline Undergraduate Degree or Higher & $0.532(0.036)$ & $0.593(0.024)$ & $0.061(0.047)$ \\
\hline Undergraduate Degree Only & $0.530(0.041)$ & $0.549(0.028)$ & $0.019(0.053)$ \\
\hline Postgraduate Degree & $0.537(0.058)$ & $0.664(0.034)$ & $0.127(0.073)$ \\
\hline Postgraduate/Undergraduate & $0.007(0.065)$ & $0.115(0.038)$ & $0.108(0.081)$ \\
\hline Sample size & 1160 & 1917 & \\
\hline
\end{tabular}

Notes: As for Table 5. 


\section{Data Appendix}

\section{Basic Processing of the LFS Data}

We use the annual Labour Force Surveys of 1981, 1986, 1991 and the quarterly Labour Force Surveys from 1996 through 2011. We drop observations from Northern Ireland to maintain comparability with the British cohort data. Employment shares are calculated for a sample of employed individuals aged between 26 and 60 . All estimates are weighted by LFS person weights.

Our highest qualification definitions are 'no qualifications', 'intermediate A qualifications', 'intermediate B qualifications', 'undergraduate degree' and 'higher degree'. Before 1996, it is not possible to disaggregate postgraduates and undergraduates in the composite graduate group because the LFS does not include Post-Graduate Certificates in Education (PGCEs) in the higher degree qualification category. PGCEs are instead included in the undergraduate level teaching qualifications. Intermediate A qualifications include school-level qualification up to and including A levels (or an equivalent level diploma via further education), whilst intermediate B include professional undergraduate level qualifications which are not a degree (like teaching and nursing qualifications). From 1996 onwards, we disaggregate the postgraduate group into those with a Masters, a PGCE, a Doctorate or those with another professional higher qualification as their highest qualification attained.

\section{Basic Processing of the NCDS and BCS Data}

We use data from the National Child Development Study (NCDS, a cohort of all individuals born in Britain in a week of March 1958) and the British Cohort Study (BCS, a cohort of all individuals born in Britain in a week of April 1970).

The education data is coded to the same five categories as for the LFS and comes from the age 33 wave of the NCDS in 1991 and the age 34 wave of the BCS in 2004.

Parental income at age 16 comes from the 1974 wave of the NCDS and the 1986 wave of the BCS. We use the data cleaned by Blanden, Gregg and Macmillan (2007, 2011), which was kindly supplied by Lindsey Macmillan. For more information, see Appendix B of Blanden, Gregg and Macmillan (2011) where issues of attrition biases to do with the parental income variable in the NCDS and BCS are discussed in detail

\section{LFS Wage Data and Sample}

Full-time weekly earnings are calculated as the logarithm of weekly earnings for all fulltime workers. Earnings numbers are deflated using the RPI deflator. We trim the sample by excluding the bottom one percent of full time workers in each year and again restrict the sample to be aged between 26 and 60 . The basic wage equations include a continuous age variable and its square, 10 dummy variables for Government Office region, as well as dummy variables for working in the private sector, being married/cohabiting and being of white ethnicity. All estimates are weighted using LFS person weights. 
For the cross-cohort comparisons with the NCDS and the BCS data, we use the 1996 and 2008 Quarterly Labour Force Survey for respondents aged between 36 and 40. We do this because we want to compare the NCDS and BCS individuals who were born in 1958 and 1970 respectively with the same birth cohorts in the LFS at around the same age. We are restricted in using 1996 as our earliest year from the LFS because we can only consistently distinguish between postgraduate and undergraduate degrees from 1996 onwards. Therefore, if we want to compare individuals born in 1958 and 1970 from the NCDS and BCS with those from the LFS using data from 1996 onwards we are forced to use age 36 onwards from the 1996 LFS. We use the age range 36 to 40 (i.e. centred on age 38) to ensure sufficiently large cell sizes for this analysis.

\section{NCDS and BCS Wage Data and Sample}

Full-time weekly earnings are calculated as the logarithm of weekly earnings for all fulltime workers and are taken from the age 33 wave of the NCDS in 1991 and the age 34 wave of the BCS in 2004. We also use the age 38 wave of the BCS in 2008 (referred to in footnote 9 of the paper). Earnings numbers are deflated using the RPI deflator. We trim the sample by excluding the bottom one percent of full time workers in each year. As with the LFS, the basic wage equations include 10 dummy variables for Government Office region, as well as dummy variables for working in the private sector, being married/cohabiting and being of white ethnicity. 